\title{
HUBUNGAN PERAN PEMBIMBING KLINIK DENGAN METODE PROBLEM BASED LEARNING PADA MAHASISWA KEBIDANAN DI RSUD CIBINONG
}

\author{
Dina Martha Fitri ${ }^{1(*)}$, Nurhidayah ${ }^{2}$ \\ STIKes Mitra RIA Husada Jakarta, Indonesia \\ marthadina@ymail.com ${ }^{1}$, nurhidayah.kila@gmail.com²
}

Received: 01 April 2020

Revised: 03 September 2020

Accepted: 22 September 2020

\begin{abstract}
PBL or problem based learning is a learning approach that uses real-world problems as a context for students to learn about critical thinking and problem-solving skills for which a clinical counselor is needed. So the purpose of research to find out "The relationship of clinical counselor role with the method of Problem Based Learning on the students practice at RSUD Cibinong in December 2017 July 2018. This research method used a quantitative research design using cross sectional approach in July 2018 population of all students who practice at RSUD Cibinong 2018 with a sample of 52 people. The data taken are primary data by using questionnaires that have been validated and reability after data obtained in data though using univariate analysis with frequency distribution and bivariate analysis using chi-square test. The results showed that PBL method was achieved as much as $(73.1 \%)$, while the other $26.9 \%$ had not been able to achieve the problem based learning method. The role of clinical counselor as educator $(51,9 \%)$, as role model as much $(55,8 \%)$, facilitator as much $(71,2 \%)$ and role as evaluator as much $(59,6 \%)$. From the result of the research, it can be concluded that there is a significant relationship between problem based learning method with the role of clinical counselor as educator $(p=0,000)$ and facilitator $(p=0,041)$ and no relation on role model role $(\mathrm{p}=0,453)$ and evaluator role $\mathrm{p}=0.677)$. The conclusions of the research conducted at RSUD Cibinong mostly achieved. In this research is expected role of clinical counselor as role model can exemplify good behavior in learners and can do evaluation in structured and make improvement based on evaluation result.
\end{abstract}

Keywords: Problem Based Learning; Clinical Counselor; Learning Evaluation

(*) Corresponding Author:

Fitri, marthadina@ymail.com, 081293145087

How to Cite: Fitri, D. M. \& Nurhidayah. (2020). Hubungan Peran Pembimbing Klinik Dengan Metode Problem Based Learning Pada Mahasiswa Kebidanan Di RSUD Cibinong. Research and Development Journal of Education, 1(1), 72-80.

\section{INTRODUCTION}

Tuntutan era globalisai membuat setiap orang harus mampu bersaing sesuai kompetensi yang dimiliki. Mahasiswa sebagai bagian dari SDM dituntut untuk mencapai kompetensi sesuai standar yang berlaku ketika lulus dari perguruan tinggi. Untuk mencapai kompetensi tersebut semua perguruan tinggi berusaha meningkatkan kualitas belajar mengajar dengan mengubah metode pembelajaran dari teacher-centered contentoriented (TCCO) menjadi student-centered learning learning (SCL) (Irvariani, 2013).

Metode pembelajaran SCL melatih berpikir kritis dan kreatif. Jenis metode SCL, salah satunya adalah metode problem based learning (PBL). PBL menawarkan banyak keuntungan, yaitu Pendidikan yang berkualitas, holistic (menyeluruh), dan bernilai tambah dalam belajar menjadi menjadi tenaga kesehatan professional pada abad ke 21 . 
Implementasi PBL akan membantu mahasiswa dalam berpikir, berperilaku dan bertindak sebagai tenaga kesehatan professional dan beretika.

Peran adalah pola tingkah laku yang diharapkan dari seseorang yang menduduki suatu jabatan atau pola tingkah laku yang diharapkan pantas dari seseorang. Oleh karena itu, seharusnya seorang pembimbing klinik diberi wewenang dan tanggungjawab yang jelas sesuai dengan perannya dalam merancang, mengelola dan mengevaluasi pembelajaran klinik terhadap peserta didik di tatanan klinik. Namun seringkali kita melihat dan merasakan keadaan yang berbeda dimana seorang pembimbing klinik sulit sekali menunjukkan kemampuannya dalam membimbing peserta didik karena berbagai sebab antara lain adalah kurangnya kepercayaan diri dan ketidakjelasan peranan yang di berikan institusi pendidikan pada para pembimbing klinik tersebut (Agustini, 2015).

Seorang pembimbing klinik merupakan seorang tenaga kesehatan yang mempunyai peran ganda yaitu sebagai tenaga kesehatan profesional dan peran sebagai pendidik (pembimbing klinik) di lahan praktek. Peran ganda tersebut menuntut seorang pembimbing klinik selain untuk menguasai ilmu dan konsep kesehatan yang harus dimiliki, juga harus mampu melaksanakan perannya sebagai pembimbing. Seorang tenaga kesehatan dalam memainkan perannya sebagai pembimbing klinik di rumah sakit, harus menguasai ilmu dan kiat dan menerapkan proses tenaga kesehatan dalam kegiatan seharihari sehingga dapat menjadi model peran bagi tenaga kesehatan lainnya (Iswahyuni, 2008).

Pembimbing klinik mengetahui peran sesungguhnya yang diharapkan dari pembimbing klinik dan dapat menerapkan pengetahuan dalam sikap dan perilaku yang tercermin dalam pelaksanaan pemberian bimbingan kepada mahasiswa. Hal ini sangat dipengaruhi latar belakang pendidikan, pengalaman kerja dan masa kerja pembimbing klinik. Perubahan paradigma metode pembelajaran berpusat pada peserta didik telah diterapkan pada beberapa perguruan tinggi baik di dunia maupun di Indonesia. Berbagai metode telah banyak ditemukan oleh para peneliti pendidikan. Pendidik harus bisa menentukan metode yang relevan terhadap suatu mata kuliah. Sehingga pembelajaran berpusat pada mahasiswa (Sumarni, 2016).

Dari hasil penelitian Prodi D-III Kebidanan STIKES Immanuel sejak TA 2012/2013 telah menggunakan kurikulum berbasis kompetensi. Secara umum, keefektifan kelompok dalam PBL di Program studi D-III Kebidanan STIKES Immanuel masih belum memadai sehingga berdampak pada rendahnya pencapaian hasil prestasi belajar. Dari hasil survey pendahuluan didapatkan data, ada beberapa institusi yang praktik di Rumah Sakit Umum Daerah Cibinong Tahun 2018. Dengan jumlah total 110 mahasiswa. Dan peneliti melakukan wawancara dengan beberapa mahasiswa yang sedang praktik di Rumah Sakit Umum Daerah Cibinong. Mahasiswa yang sedang praktik menyampaikan pembimbing kurang membimbing, bimbingan yang diberikan oleh pembimbing klinik juga belum optimal, pembimbing klinik kurang memberikan jasa bimbingan yang cepat dan kurang menanggapi keluhan yang dihadapi mahasiswa, pembimbing klinik kurang perhatian terhadap kebutuhan pembelajaran mahasiswa dan kurangnya peran pembimbing klinik disebabkan oleh keterbatasan waktu dalam pelaksanaan bimbingan.

\section{LITERATURE REVIEW}

\section{Problem Based Learning}

Pembelajaran dan penggalian berbasis masalah (problem based learning/inquiry) adalah belajar dengan memanfaatkan masalah dan mahasiswa harus 
melakukan pencarian atau penggalian informasi (inquiry) untuk dapat memecahkan masalah tersebut. Pada umumnya, terdapat 4 langkah yang perlu dilakukan mahasiswa dalam metode ini, yaitu menerima masalah, melakukan pencarian data dan informasi, mengolah data dan mengaitkan data dengan masalah dan menganalisis pemecahan masalah pembelajaran dan penggalian berbasis masalah (Taufik, 2010).

Problem Based Learning merupakan pembelajaran metakognisi dan pembelajaran terstuktur dengan menanyakan kepada mahasiswa untuk mengemukakan strategi mereka dalam menyelesaian masalah mengenai definisi, informasi, analisis data dan membangun hipotesis serta penilaian yang dibedakan dengan strategi dan penyampaian yang disebar luaskan oleh mahasiswa lain dan strategi pengajar (Rusman, 2013).

Menurut Edward de Bono, Pendidikan bukanlah tujuan kita. Pendidikan harus mempersiapkan peserta didik untuk hidup. Maka dengan PBL kita memiliki peluang untuk membangun kecakapan hidup (life skills) peserta didik, peserta didik terbiasa mengatur dirinya sendiri (self directed), berfikir metakognitif (reflektif dengan pikiran dan tindakannya), berkomunikasi dan berbagai kecakapan terkait. Menurut Smith yang khusus meneliti berbagai dimensi manfaat diatas menemukan bahwa peserta didik akan meningkatkan kecakapan pemecahan masalanya, lebih mudah mengingat, meningkatkan pemahamanya, meningkatkan pengetahuan yang relevan dengan dunia praktik, mendorong mereka penuh pemikiran, membangun kempuan kepemimpinanan dan kerja sama, kecakapan belajar dan motivasi pembelajar.

Tabel 1.

Tahap -Tahap Model PBL.

Fase - fase

Perilaku Dosen

Fase 1

Orientasi siswa kepada masalah

Menjelaskan tujuan pembelajaran, menjelaskan logistic yang dibutuhkan, terlibat aktif dalam memecahkan masalah

Fase 2

Mengorganisasikan siswa

Membantu siswa dalam mengorganisasikan tugas belajar yang berhubungan dengan masalah tersebut

Fase 3

Mendorong siswa untuk mencari informasi

Membim bing penyelidikan individu dan kelompok yang sesuai, melaksanakan eksperimen untuk mendapatkan penjelas dan pemecahan masalah

Fase 4

Mengembangkan dan menyajikan hasil karya

Fase 5

Membantu mahasiswa dalam merencanakan dan meyiapkan karya/tugas.

Menganalisis dan mengevaluasi proses pemecahan masalah

Mengevaluasi hasil belajar yang telah

diselesaikan dalam kelompok, mempresentasikan hasil kerja

Sumber : Peneliti

\section{Bimbingan Klinik}

Untuk mencapai tingkat kemampuan yang harus dimiliki mahasiswa, dilaksanakan bimbingan praktek klinik. Peran adalah serangkaian perilaku yang diharapkan dari seseorang dalam kaitannya dengan statusnya dalam masyarakat. Secara umum peran dan fungsi pembimbing klinik yaitu :

1) Sebagai educator (guru/pendidik) 
Sebagai pendidik, berperan dalam mendidik memberi pendidikan dan pemahaman kepada mahasiswa dalam bentuk desiminasi ilmu kepada peserta didik. Biasanya dalam ruangan dikenal dengan pembimbing klinik yang berperan dalam memberikan pendidikan kepada para mahasiswa yang sedang menjalankan praktik di RS / Puskesmas.

2) Sebagai care giver (pemberi asuhan)

Sebagai pelaku/pemberi asuhan dapat pembimbing klinik memberikan pelayanan secara langsung dan tidak langsung kepada klien, menggunakan pendekatan yang meliputi: melakukan pengkajian dalam upaya mengumpulkan data dan informasi yang benar, menegakkan diagnosa keperawatan berdasarkan hasil analisis data, merencanakan intervensi keperawatan sebagai upaya mengatasi masalah yang muncul dan membuat langkah/cara pemecahan masalah, melaksanakan tindakan keperawatan sesuai dengan rencana yang ada dan melakukan evaluasi berdasarkan respon klien terhadap tindakan keperawatan yang telah dilakukan.

3) Sebagai Role Model

Pembimbing klinik dapat memberikan contoh yang baik dalam bidang kesehatan kepada individu, keluarga, kelompok dan masyarakat serta dapat memberikan asuhan kebidanan dan kesehatan.

Ada beberapa faktor yang Mempengaruhi Peran Pembimbing Klinik. Menurut Hannie (2007), Peran dipengaruhi oleh berbagai faktor dibawah ini yang terkait dengan pengetahuan yang harus dimiliki sebagai sumber peran. Faktor tersebut terdiri dari faktor internal dan eksternal, yaitu:

1) Faktor Internal

a) Pendidikan berarti bimbingan yang diberikan seseorang pada orang lain terhadap sesuatu hal agar mereka dapat memahami.

b) Lingkungan pekerjaan dapat menjadikan seseorang memperoleh pengalaman dan pengetahuan baik secara langsung maupun secara tidak langsung.

c) Umur seseorang akan terjadi perubahan pada aspek fisik dan psikologis (mental).

d) Minat adalah keinginan yang tinggi terhadap sesuatu.

e) Pengalaman merupakan pengalaman yang kurang baik seseorang akan berusaha untuk melupakan obyek tersebut serta secara psikologis timbul kesan yang sangat mendalam dan membekas dalam emosi kejiwaannya, dan akhirnya dapat pula membentuk sikap positif dalam kehidupannya.

f) Faktor Eksternal

a) Kebudayaan

Lingkungan sekitar, kebudayaan dimana kita hidup dan dibesarkan mempunyai pengaruh besar terhadap pembentukkan sikap kita. Apabila dalam suatu wilayah mempunyai budaya untuk menjaga kebersihan lingkungan maka sangat mungkin masyarakat sekitarnya mempunyai sikap untuk selalu menjaga kebersihan lingkungan,karena lingkungan sangat berpengaruh dalam pembentukkan sikap pribadi atau sikap seseorang.

b) Informasi

Kemudahan memperoleh informasi dapat membantu mempercepat seseorang memperoleh pengetahuan yang baru

\section{Penelitian yang berhubungan peran pembimbing dengan metode PBL}

Penelitian ini dilakukan oleh Imelda M.G. Sianipar, dkk (2007), yang berjudul Hubungan Kinerja Tutor dan Kualitas Kasus Skenario Terhadap Keefektifan Kelompok pada metode PBL. Penggunaan metode PBL di Program Studi D-III 
Kebidanan Sekolah Tinggi Ilmu Kesehatan Immanuel dirasakan belum memberi dampak yang positif terhadap kemampuan mahasiswa. Kualitas kasus pada skenario dan kinerja tutor merupakan faktor penyebab yang berpengaruh terhadap keefektifan kelompok dan berdampak pada pencapaian hasil prestasi belajar. Tujuan penelitian ini untuk menganalisis hubungan kinerja tutor dan kualitas kasus pada skenario terhadap keefektifan kelompok pada metode belajar PBL. Metode penelitian adalah crosssectional study terhadap 83 responden dari populasi mahasiswa semester III yang mengikuti pembelajaran PBL.

Hasil penelitian menyimpulkan peran tutor dalam proses tutorial sebagai fasilitator dalam mengaktifkan kelompok sehingga memungkinkan kelompok dapat berjalan efektif. Demikian juga masalah dalam skenario merupakan pemicu dalam merangsang mahasiswa untuk belajar bekerjasama dan aktif. Simpulan pada penelitian ini adalah terdapat hubungan antara kinerja tutor dan kualitas kasus pada skenario dengan keefektifan kelompok, dan hubungan kinerja tutor lebih besar dibandingkan dengan kualitas kasus pada metode belajar PBL di Program D-III Kebidanan.

\section{METHODS}

Desain penelitian ini merupakan penelitian kuantitatif dengan metode yang digunakan adalah metode analitik dengan pendekatan Cross Sectional. Untuk pengambilan data ini dilakukan dalam waktu bersamaan baik untuk variabel indenpenden maupun variabel dependen. Data yang diperoleh pada penelitian ini dianalisis untuk mengetahui hubungan peran pembimbing klinik dengan metode Problem Based Learning. Penelitian ini menggunakan skala Gutman dan Skala likert. Skala Gutman menggunakan dikatakan Ya diberi score 1, Tidak diberi score 0 . Ada 2 bentuk skala likert yaitu, untuk pertanyaan positif sebagai berikut : sangat setuju $(S S)=4$, setuju $(S)=3$, tidak setuju $(\mathrm{TS})=2$, sangat tidak setuju $(\mathrm{STS})=1$, dan pernyataan negatif dikonversikan sebagai berikut: sangat setuju $(\mathrm{SS})=1$, setuju $(S)=2$, tidak setuju $(\mathrm{TS})=3$, sangat tidak setuju (STS)=4. Pernyataan negatif dikonversikan supaya dapat dijumlahkan dengan pernyataan positif dan diambil rata-ratanya.

\section{RESULTS \& DISCUSSION}

Setelah di lakukan pengolahan data pada penelitian mengenai hubungan peran pembimbing klinik dengan metode PBL pada mahasiswa yang praktik klinik di RSUD Cibinong Tahun 2018, dengan jumlah responden 52 mahasiswa.

\section{Gambaran Metode Problem Based Learning}

Tabel 2.

Distribusi Frekuensi Metode PBL dan Peran Pembimbing

\begin{tabular}{lcc}
\hline \multicolumn{1}{c}{ Variabel } & Distribusi Frekuensi & \\
& $\mathbf{N}$ & \% \\
\hline Metode PBL & & \\
Tercapai & 38 & 73,1 \\
Tidak Tercapai & 14 & 26,9 \\
\hline
\end{tabular}




\begin{tabular}{lll}
\hline Peran Edukator & & \\
Baik & 27 & 51,9 \\
Kurang & 25 & 48,1 \\
& & \\
Peran Role Model & & 55,8 \\
Baik & 29 & 44,2 \\
Kurang & 23 & \\
Peran Fasilitator & & 71,2 \\
Baik & 37 & 28,8 \\
Kurang & 15 & \\
& & 59,6 \\
Peran Evaluator & & 40,4 \\
Baik & 31 & 100 \\
Kurang & 21 & \\
& & \\
Total & 52 &
\end{tabular}

Tabel 5.1 menunjukan hasil bahwa sebagian besar responden $(73,1 \%)$ mampu mencapai program pembelajaran dengan metode PBL, sedangkan 26,9\% lainya belum mampu mencapai program pembelajaran dengan metode PBL. Ditinjau dari peran pembimbing klinik sebagian besar baik $(51,9 \%)$, peran pembimbing klinik sebagai role model sebagian besar baik $(55,8 \%)$, peran pembimbing klinik sebagai fasilitator sebagain besar baik $(71,2 \%)$ dan peran pembimbing klinik sebagai evaluator sebagian besar juga baik $(59,6 \%)$.

\section{Analisa Bivariat}

Tabel 3.

Hubungan Peran Pembimbing Klinik Dengan Metode PBL

\begin{tabular}{|c|c|c|c|c|c|c|c|}
\hline \multirow{3}{*}{ Peran Pembimbing Klinik } & \multicolumn{4}{|c|}{ Metode PBL } & \multirow{3}{*}{ Jumlah } & \multirow{3}{*}{$\begin{array}{c}P \\
\text { Value }\end{array}$} & \multirow{3}{*}{ OR } \\
\hline & \multicolumn{2}{|c|}{ Tercapai } & \multicolumn{2}{|c|}{ Tidak Tercapai } & & & \\
\hline & $\mathbf{n}$ & $\%$ & $\mathbf{N}$ & $\%$ & & & \\
\hline Peran Edukator & & & & & & & 28,1 \\
\hline Baik & 26 & 96,3 & 1 & 3,7 & $27(100)$ & 0,000 & $(3,294-$ \\
\hline Kurang & 12 & 48 & 13 & 52 & $25(100)$ & 28 & $240,814)$ \\
\hline Peran Role Model & & & & & & & \\
\hline Baik & 20 & 69 & 9 & 3,1 & $29(100)$ & & 0,617 \\
\hline Kurang & 18 & 78,3 & 5 & 21,7 & $23(100)$ & 0,453 & $\begin{array}{l}(174- \\
2,187)\end{array}$ \\
\hline Peran Fasilitator & & & & & & & 3,75 \\
\hline Baik & 30 & 81,1 & 7 & 18,9 & $37(100)$ & 0,041 & $(1,016-$ \\
\hline Kurang & 8 & 53,3 & 7 & 46,7 & $15(100)$ & & $13,843)$ \\
\hline Peran Evaluator & & & & & & & \\
\hline Baik & 22 & 71 & 9 & 29 & $31(100)$ & 0677 & 0,764 \\
\hline Kurang & 16 & 76,2 & 5 & 23,8 & $21(100)$ & $0,0 / 1$ & $(215--$ \\
\hline Total & 38 & 73,1 & 14 & 29,6 & $52(100)$ & & $2, / 17)$ \\
\hline
\end{tabular}

Sumber : Peneliti 
Tabel 5.2 menunjukan presentase hasil analisa bivariat tentang hubungan peran pembimbing klinik sebagai edukator dengan metode PBL didapatkan data bahwa responden yang peran edukator pembimbing kliniknya baik sebanyak 96,3\% program pembelajaran PBL nya tercapai dan 3,7\% tidak tercapai. Namun pada responden yang peran edukator pembimbing kliniknya kurang sebanyak 52\% program pembelajaran PBL nya tidak tercapai dan $48 \%$ tercapai.

Hasil analisa statistik dengan chi square didapatkan $P$ Value $=0,000<0,05$ dengan demikian dapat disimpulkan bahwa ada hubungan yang bermakna peran edukator pembimbing klinik dengan metode PBL. Responden yang peran edukator pembimbing kliniknya baik 28 kali lebih baik dalam mencapai program pembelajaran PBL daripada yang peran edukator pembimbing kliniknya kurang $(\mathrm{OR}=28,1)$. Untuk hubungan peran pembimbing klinik sebagai role model dengan metode PBL didapatkan data bahwa responden yang peran role model pembimbing kliniknya baik sebanyak 69\% program pembelajaran PBL nya tercapai dan 31\% tidak tercapai. Namun pada responden yang peran role model pembimbing kliniknya kurang sebanyak 78,3\% program pembelajaran PBL nya juga tercapai dan $21,7 \%$ tidak tercapai. Hasil analisa statistik dengan chi square didapatkan $P$ Value $=0,453>0,05$ dengan demikian dapat disimpulkan bahwa tidak ada hubungan yang bermakna peran role model pembimbing klinik dengan metode PBL.

Untuk hubungan peran pembimbing klinik sebagai fasilitator dengan metode PBL didapatkan data bahwa responden yang peran fasilitator pembimbing kliniknya baik sebanyak $81,1 \%$ program pembelajaran PBL nya tercapai dan $18,9 \%$ tidak tercapai. Namun pada responden yang peran fasilitator pembimbing kliniknya kurang sebanyak $53,3 \%$ program pembelajaran PBL nya juga tercapai dan $46,7 \%$ tidak tercapai. Hasil analisa statistik dengan chi square didapatkan $P$ Value $=0,041<0,05$ dengan demikian dapat disimpulkan bahwa ada hubungan yang bermakna peran fasilitator pembimbing klinik dengan metode PBL. Nilai responden dengan $(\mathrm{OR}=3,75)$ peran fasilitator pembimbing kliniknya 3 kali lebih baik dalam mencapai program pembelajaran PBL dari pada yang peran fasilitator pembimbing kliniknya kurang

Untuk hubungan peran pembimbing klinik sebagai evaluator dengan metode PBL didapatkan data bahwa responden yang peran evaluator pembimbing kliniknya baik sebanyak $71 \%$ program pembelajaran PBL nya tercapai dan $29 \%$ tidak tercapai. Namun pada responden yang peran evaluator pembimbing kliniknya kurang sebanyak 76,2\% program pembelajaran PBL nya juga tercapai dan 23,8\% tidak tercapai. Hasil analisa statistik dengan chi square didapatkan $P$ Value $=0,677>0,05$ dengan demikian dapat disimpulkan bahwa tidak ada hubungan yang bermakna peran evaluator pembimbing klinik dengan metode PBL.

Hasil penelitian menunjukan bahwa sebagian besar responden mampu mencapai metode PBL. Hal ini sesuai dengan teori PBL atau pembelajaran berbasis masalah adalah suatu pendekatan pembelajaran yang menggunakan dunia nyata sebagai suatau konteks untuk mahasiswa sebagai media belajar tentang berpikir kritis dan keterampilan pemecahan masalah, serta untuk memperoleh pegetahuan dan konsep yang esensial dari materi perkuliahan. Dengan membuat permasalahan sebagai tumpuan pembelajaran mahasiswadidorong untuk mecari informasi yang diperlukan dalam penyelesaian masalah. Hasil penelitian menunjukan bahwa ada hubungan yang spesifik antara peran pembimbing klinik sebagai edukator dengan program PBL $(\mathrm{p}=0,000)$. PBL adalah cara pembelajaran yang mendorong mahasiswa dalam mencari informasi dalam memecahkan masalah. Program PBL menitikberatkan mahasiswa sebagai orang yang belajar, membiasakan mahasiswa belajar mandiri dan membuat mahasiswa belajar lebih aktif. Metode PBL ini sangat membantu program Student Central Learning karena dengan sistem ini pembelajaran menjadi berpusat kepada mahasiwa, bukan lagi kepada dosen. Hasil penelitian ini sesuai dengan hasil penelitian yang dilakukan oleh Sianipar (2016). 
Dalam penelitianya tentang hubungan kerja tutor dan kualitas kasus skenario terhadap keefektifan kelompok pada metode belajar PBL. Hasil penelitian tersebut menunjukan bahwa ada hubungan kinerja tutor dengan kefektifan kelompok pada metode belajar PBL $(\mathrm{p}=0,001)$.

Hasil penelitian menunjukan bahwa tidak ada hubungan antara peran pembimbing klinik sebagai Role Model dengan program PBL $(\mathrm{p}=0,453)$. Dalam pembelajaran praktik klinik ada beberapa hal yang berpengaruh dalam proses pembelajaran tersebut. Rumah sakit merupakan fasilitas yang mutlak harus ada karena menjadi menjadi tempat pengembangan dan pengalaman belajar klinik. Rumah sakit merupakan tempat dimana mahasiswa dapat melihat dan mengalami kondisi yang sebenarnya. Hasil penelitian menunjukan bahwa ada hubungan peran pembimbing klinik sebagai fasilitator dengan metode PBL $(p=0,041)$. Kegiatan pembelajaran klinik merupakan suatu kegiatan belajar mengajar dalam konteks pelayanan nyata. Maksudnya mahasiswa belajar memberikan pelayanan kepada pasien yang membutuhkan pelayanan kesehatan. Dalam hal ini mahasiswa belajar bekerja dengan standar pelayanan profesi. Dalam pemenuhan hal tersebut mahasiswa membutuhkan fasilitas-fasilitas tertentu untuk menunjang keberhasilan praktik klinik.

Hasil penelitian menunjukan bahwa tidak ada hubungan pean pembimbing klinik sebagai evaluator dengan metode PBL $(p=0,677)$. Sebagai kegiatan yang bertujuan untuk menilai keberhasilan peserta didik, evaluasi memegang peranan yang sangat penting. Sebab melalui proses evaluasi seorang pembimbing akan menentukan apakah peserta didik sudah mampu memenuhi dan memahami pencapaian kometesi yang diharapkan, atau malah sebaliknya.

\section{CONCLUSION}

Berdasarkan hasil penelitian maka dapat disimpulkan bahwa:

1. Hasil penelitian didapatkan peran pembimbing klinik di Rumah Sakit Umum Daerah Cibinong dengan menggunakan metode PBL sebagian besar tercapai sebanyak $73 \%$. $\mathrm{Hal}$ ini di dukung oleh peran pembimbing klinik yaitu peran sebagai educator 51,9\%, role model $55,8 \%$, fasilitator $71,2 \%$ dan peran sebagai evaluator $59,6 \%$.

2. Ada hubungan antara peran pembimbing klinik sebagai educator dan fasilitator dengasn penggunaan metode PBL.

3. Tidak ada hubungan antara peran pembimbing klinik sebagai role model dan evaluator dengan penggunaan metode PBL.

\section{REFERENCES}

Agustini, Ni Made. (2015) Hubungan Peran Pembimbing Klinik dengan Kepuasan Mahasiswa dalam Praktek Lapangan Klinik Keperawatan Di Irna C RSUP Sanglah Denpasar.

Arikunto, S. (2013). Prosedur Penelitian Suatu Pendekatan Praktik. Jakarta: Rineka Cipta.

Asmadi. (2008). Konsep Dasar Keperawatan. Jakarta: EGC.

Azwar. (2002). Sikap Manusia dan Pengukuranya. Jakarta: PT. Rineka Cipta.

Hidayat, A. (2002). Pengantar Pendidikan Keperawatan. Jakarta: Sagung Seto.

Notoatmodjo S. (2012). Metodologi Penelitian Kesehatan. Jakarta: Rineka Cipta.

Rusman. (2013). Seri Manajemen Sekolah Bermutu Model-Model Pembelajaran Mengembangkan dan Pemberdayaan Profesionalisme. Jakarta: Rajawali Pers. 
Fitri, D. M. \& Nurhidayah / Reseacrh and Development Journal of Education, (Special Edition), $72-$

Sumarni, R., Idjradinata, P. S., Husen IR, Husin F, Sukandar H, Program M, et al. (2016). Pengaruh Implementasi Metode Problem Based Learning terhadap Hasil Belajar MateriKeluarga Berencana (Dalam Mata Kuliah Kesehatan Reproduksi dan KeluargaBerencana I pada Program Studi Kebidanan (D-III) STIKes Jenderal Achmad Yani Cimahi TA.2014/2015), (38).

Taufik, A. (2010). Inovasi Pendidikan Melalui Problem Based Learning. Jakarta. 